\title{
Islamic Education Teachers Strategy in Implementing Multiculturalism Based Education
}

\author{
Moh Padil ${ }^{{ }^{*}}$,Fatimah Saguni ${ }^{2}$, and Adawiyah Adawiyah ${ }^{3}$ \\ ${ }^{1}$ Islamic Education Department, Postgraduate, Institut Agama Islam Negeri Palu \\ 2 Islamic Education Department, Postgraduate, Institut Agama Islam Negeri Palu \\ ${ }^{3}$ Islamic Education Department, Postgraduate, Institut Agama Islam Negeri Palu
}

ABSTRACT

This study discusses teachers strategy of Islamic Education Implementing Multiculturalism Based Education. In conducting the study, we used a qualitative case study method. The case of this study was a stateb senior high school in Palu city. Data were gathered through direct field observation, in-depth interviews which involve teachers and the school principle. We also analyzed written material, such as the school teaching activities, to understand how the teacher strategies in implementing multicultural based education as the senior high school. Our study found that the teachers at the government senior high school made learning planning that emphasizes the integration of multicultural values, fairness, responsibility, religion, awareness of rights and obligations, equality, tolerance, respect for diversity, honesty, discipline contained in the learning program plan and in the syllabus. Then the implementation of multicultural education learning is carried out through a sociological approach that contains multicultural values.

\section{ARTICLE \\ INFORMATION}

Keywords:

Teachers strategies, reading Quran, Quran recitation, reading difficulties. 


\section{Introduction}

The practice of violence in the name of religion, from fundamentalism, radicalism, to terrorism, has recently become increasingly widespread in Indonesia. The unity and integrity of the nation is currently being tested for its existence. Various indicators that show signs of national division are easy to read transparently. Conflicts in Ambon, Papua, and Poso, like fire in husks, can explode at any time, although they can be suppressed many times. This incident not only claimed many lives, but also destroyed hundreds of places of worship (both mosques and churches).

When observed, religion should be a driving force for mankind to always uphold peace and improve welfare for all people on this earth. However, the reality is that religion is one of the causes of violence and the destruction of mankind. Therefore, preventive efforts are needed so that the problem of religious conflict will not recur in the future. For example, by intensifying dialogue forums between religious communities and beliefs (interfaith dialogue), building a more pluralist and inclusive religious understanding, and providing education about pluralism and religious tolerance through schools (educational institutions). ${ }^{1}$

On the other hand, religious education provided in schools in general also does not turn on good multicultural education, and even tends to be the opposite. As a result, social conflicts are

\footnotetext{
${ }^{1}$ M. Ainul Yaqin, Pendidikan Multikultural Cross-Cultural Understanding untuk Demokrasi dan Keadilan (Yogyakarta: Pilar Media, 2005), H. 35.
}

often exacerbated by the existence of religious legitimacy taught in religious education in conflict-prone regional schools. This makes conflicts have roots in fundamental religious beliefs so that violent social conflicts are increasingly difficult to overcome, because they are understood as part of their religious vocation. $^{2}$

Some of the main principles that need to be stated before discussing multicultural religious education are: 1 ) Islam is a universal religion. Islam is not intended for a particular ethnic group, but as rahmatan lil alamin; 2) Islam respects other religions and beliefs. Islam also teaches that there is no compulsion in religion; 3) Islam is also a religion that is open to be verified; 4) Islam also emphasizes that diversity in human life is natural, the differences start from different genders, ethnicities, and nations. Differences exist in order to get to know each other; 5) Islam has a fairly clear history related to a pluralistic life as shown by the Prophet himself when building civil society in Medina. These basic principles need to be used as a reference in discussing multicultural education.

The importance of multicultural education in Indonesia has been discussed by education experts since 2000 through symposiums, workshops, as well as various writings in the mass media and books. Munir Mulkhan (2004), Musa Asy'ari (2004), and Azyumardi Azra (2002), are among

2 Musa Asy'arie, “Pendidikan Multikultural dan Konflik Bangsa, (Yogyakarta: Logung Pustaka, 2005), H. 87-98. 
Indonesian education experts who discuss the importance of multicultural education in Indonesia. ${ }^{3}$ They put forward the discourse based on the fact that Indonesia is a country that has many problems regarding the existence of various social, ethnic, and religious groups. 4

In their view, the problem is caused by poor management of the existence of multiethnic, multicultural and multireligious in Indonesia. The indicator can be seen in the efforts of uniformity or often called monoculturalism politics in aspects of life carried out by the government during the New Order era. During the New Order in power, the government ignored the existing differences, both in terms of ethnicity, language, religion and culture.

Based on the problems as above, multiculturalism education offers an alternative through the application of strategies, concepts and educational models based on the use of diversity in society. ${ }^{5}$ Especially in students. Such as ethnic diversity, culture, language, religion, social status, gender, age and racial abilities and so on.

Although multicultural education is a relatively new education in the world of education. However, this has actually been initiated long ago. Just not

\footnotetext{
${ }^{3}$ Abdullah Aly, Pendidikan Islam Multikultural di Pesantren, (Yogyakarta: Pustaka Belajar, 2011), H. 1

4 Rusli, Rusli. (2013). The Role of Musalahah in Conflict Resolution: A Historical Perspective. HUNAFA: Jurnal Studia Islamika, 10(2), 203-220.

${ }^{5}$ Choirul Mahfud, Pendidikan Multikultural, (Yogyakarta: Pustaka Pelajar, 2014), H. 89
}

optimal. Historically, before World War II, it could be said that multicultural education was not yet known. In fact, education is used as a political tool to perpetuate the power that monopolizes the education system for certain groups. In other words, multicultural education is a new phenomenon in the association of human beings who long for equal rights, including the right to get the same education for everyone. ${ }^{6}$

Practically, the application of strategies and concepts of multicultural education is not only aimed at making it easier for students to understand certain lessons learned (knowledges-oriented), ${ }^{7}$ but will also increase their understanding and awareness so that they always behave in a humanist, multiculturalist and democratic (valuesoriented) manner. Likewise, a teacher does not only master the material professionally, but also must be able to instill the core values of multicultural education.

Learning activities are two things that cannot be separated, because students do learning activities, because teachers teach, or teachers teach so students learn. Therefore, both are an integration, so the approach or teaching method used by the teacher determines the learning activities carried out by students. In the educational process, the teacher must have a strategy. It is

\footnotetext{
${ }^{6}$ Ibid, H. 126

${ }^{7}$ Rusli, Rusli, \& Nurdin, Nurdin. (2021). Understanding Indonesia millennia Ulama online knowledge acquisition and use in daily fatwa making habits. Education and Information Technologies. doi: 10.1007/s10639-021-10779-7
}

e-ISSN: 2715-4572

p-ISSN: 2716-1439 
intended that students can learn effectively and efficiently and hit the expected goals. One of the steps to having that strategy is to master presentation techniques, usually also called learning methods. 8 The method has a very significant position to achieve the goal. Even the method as an art in transferring knowledge or subject matter to students is considered more significant with the material itself.

With regard to Islamic education with a multicultural perspective, it is offered to answer questions about building awareness of accepting differences as a form of multicultural awareness. The author through this scientific work tries to examine more deeply about the importance of an Islamic religious education with a multicultural perspective in SMA Negeri 2 Palu. This paper is limited to learning Islamic Religious Education covering materials, methods, and evaluations.

\section{Literature review}

\subsection{Definition of Multicultural Education}

Multicultural education is a process of developing all human potentials that respects plurality and heterogeneity as a consequence of cultural, ethnic, ethnic, and religious diversity. ${ }^{9}$ Multicultural education

${ }^{8}$ Syaiful Bahri Djamarah dan Aswan Zain, Strategi Belajar Mengajar (Jakarta: Rineka Cipta, 2006), H. 70

${ }^{9}$ Rusli, Rusli. (2018). Fikih Ekologi dan Kearifan Tradisional: Tinjauan Terhadap Konsep Ihya' al-Mawat dan Hima. HUNAFA: Jurnal Studia Islamika, 5(3), 287-298. emphasizes a philosophy of cultural pluralism into the education system based on the principles of equality, mutual respect and acceptance and understanding and a moral commitment to social justice.

Multicultural education began with the development of ideas and awareness about interculturalism after World War II. The emergence of the idea and awareness of interculturalism is not only related to developments in international politics regarding human rights, independence from colonialism, racial discrimination, and others, but also due to the increasing plurality in Western countries themselves as a result of increased migration from newly independent countries to America. and Europe. Multicultural education is actually an attitude of caring and understanding (difference) or the political recognition of people from minority groups. Multicultural education looks at society more broadly. Based on the basic view that indifference and non-recognition are not only rooted in the inequality of racial structures, but the multicultural education paradigm includes subjects regarding injustice, poverty, oppression, and underdevelopment of minority groups in various fields.

Etymologically the term multicultural education consists of two terms, namely education and multicultural. Education means the process of developing attitudes and behavior of a person or group in an effort to mature through teaching, training, processes and ways of 
educating. And multicultural is defined as cultural diversity, various politeness.

Meanwhile, in terms of terminology, multicultural education means the process of developing all human potentials that respect plurality and heterogeneity as a consequence of cultural, ethnic, and religious diversity. This understanding has very broad implications in education, because education is understood as an endless process or a lifelong process. Thus, multicultural education requires the highest respect and appreciation for human dignity.

Multiculturalism is an ideology that recognizes and glorifies differences in equality, both individually and culturally. ${ }^{10}$

In simple terms, it can also be interpreted as an acknowledgment of cultural pluralism. Cultural pluralism is not something that is given but is a process of internalizing values in a community. Although the meaning of culture is so diverse, there are several points of commonality that bring together the diversity of existing definitions.

Multiculturalism on one hand is an understanding and on the other hand is an approach that offers a cultural paradigm to understand the differences that have existed in the midst of our society and the world. Differences if not managed properly will lead to conflict, which has even recently become a

${ }^{10}$ Yaya Suryana, Pendidikan Multikultural; Suatu Upaya Pengamatan Jati Diri Bangsa KonsepPrinsip Praktek, (Bandung: Pustaka Setia, 2015), H. 99 reality. One of the conditions for an effective multicultural attitude is if we want to accept the fact that humans are not perfect creatures, humans are creatures who always need other humans.

Multiculturalism is not just a discourse, but an ideology that must be fought for. Multiculturalism is needed as a foundation for the establishment of democracy. Human rights and the welfare of the community's life. Multiculturalism is not an ideology that stands alone, separate from other ideologies. However, multiculturalism still requires a set of concepts that support it.

To be able to understand multiculturalism, a knowledge base is needed in the form of building relevant concepts that support the existence of multiculturalism in human life. Various concepts relevant to multiculturalism include: democracy, justice and law, cultural values and ethos, togetherness and equal differences. Ethnicity, ethnic culture, cultural expressions, domain and public, human rights, community cultural rights and others.

Multicultural education is an approach to teaching and learning that is based on democratic values and beliefs and sees social diversity and world independence as part of cultural plurality. Multicultural and education are a series of words that contain essence and consequences that cannot be separated. In multiculturalism there is study material that forms the basis for the implementation of both education which is equally important. In education, there are cultural foundations

e-ISSN: 2715-4572

p-ISSN: 2716-1439 
and roots that are extracted from the cultural values of society.

Multicultural education is a process that can be interpreted as the development of attitudes and behavior of a person or group of people in an effort to mature humans through teaching, training, processes, actions and ways of educating that respect plurality and heterogeneity in a humanistic manner. Multicultural education is a learning strategy that makes students' diverse cultural backgrounds used as an effort to improve student learning in the classroom and school environment. These are designed to support and expand the concepts of culture, difference, equality and democracy.

There are also those who say that multicultural education is an idea or concept of an educational renewal movement and process. This concept arises on the basis that all students, regardless of type and status, have the same opportunity to study in formal schools.

Multicultural education usually has the following characteristics:

a) Aims to form human culture and create a cultured society.

b) Material: teaches noble human values, national values, and group values.

c) The democratic method respects aspects of differences and cultural diversity of nations and groups.

d) Evaluation is determined on the assessment of student behavior which includes perceptions, appreciation, and actions against other cultures.
The understanding of plurality includes all differences and diversity, while culture itself cannot be separated from these four points, including the important ones, namely flow (religion), race, ethnicity and culture. In multicultural education means the acknowledgment of these four important points to program the ongoing multicultural education. Recognition of these four important points characterizes multicultural education.

\subsection{Multicultural Values}

The following are details about Islamic concepts or teachings that are compatible with multicultural values, including:

\section{a. Pluralism}

The language comes from English plural, in the sense of diversity in society. In terms, pluralism is not just a situation or fact that is plural. More than that, pluralism is substantially manifested in the attitude of recognizing each other as well as appreciating, respecting, maintaining and even developing or enriching situations that are plural or many.

In detail, pluralism is the existence or tolerance of ethnic diversity or cultural groups or in a society or country as well as the diversity of beliefs or attitudes within a body, institution and so on. This kind of pluralism is called social pluralism. To realize and support this concept, tolerance is needed, because tolerance without a pluralistic attitude will not guarantee the achievement of lasting harmony 
between religious communities and vice versa.

No one in this world can deny the fact that the universe is plural, diverse, colorful and different. Diversity is the law of the universe or sunnatullah. In other words, diversity is God's will in the universe.

Pluralism in the Qur'an has been mentioned since the creation of man. God as a transcendent essence created man from a pair of male and female and from both of them made people into tribes and nations (Surah Al-Hujurat [49]: 13

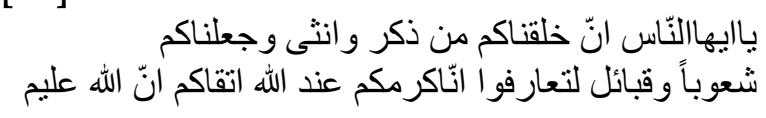

Meaning: "O mankind, I created you from male and female, and made you into tribes and nations to get to know each other, indeed the most honorable among you in the sight of Allah is the most pious among you. Verily Allah is All-Knowing.

So, naturally humans created by God are very varied and different. In addition to testing humans to compete to show their best efforts and devotion to God in a plural world. The main purpose of the creation of different human beings is for the development of knowledge and mutual understanding. The existence of differences encourages people to ask questions, analyze and try to think hard to understand each other. Differences also require people to promote harmony and cooperation with each other. God created humans in different forms not as a source of division or polarization of society.

The attitudes and views of the Qur'an regarding pluralism above were practiced by the prophet Muhammad SAW and declared as the principle of living together in the community of the nation. Prophet Muhammad SAW arrived in Medina (Yastrib), he saw a pluralistic society, both in terms of ethnicity and religious beliefs. Medina at that time consisted of three major religions: Muslims, polytheists and Jews. The Muslims consisted of the Ansar and the Muhajirin, the Jews consisted of the Nadir, the Qainuqa and the Quraizah. While the polytheists are Arabs who worship idols.

\section{b. Equality}

The Qur'an also emphasizes that the people of the world, regardless of ethnicity, and race, are united in the necessity of their obedience to one God the Creator. In another verse, the Qur'an emphasizes the principle of unity in diversity, Allah says in the QS. Alanbiya [21]: 92 :

$$
\text { انّ هذه امتّكم امّةً و احدةً و انا ربّكم فاعبدون }
$$

Meaning: verily this (religion of monotheism) is the religion of all of you; one religion and I am your Lord, so worship Me.

Emphasis on the universal message of God, that the task of all human beings is to serve God. The Qur'an acknowledges the existence of people before Muhammad and their holy book. The Qur'an repeatedly confirms that the truth that existed in the books before Muhammad came from the same God, and that the Qur'an is the last revelation which is the completion of the previous revelations. This is confirmed in the Qur'an QS. Ali-Imran [3]: 84 : 
قل امنّا بالله وما انزل علينا وما أنزل على ابر هيما

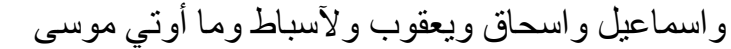

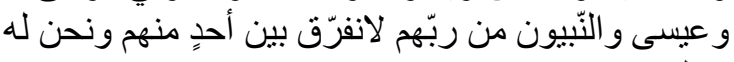

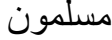

Meaning: Say: We believe in Allah and what was revealed to $U$ s and revealed to Ibrahim, Ismail, Ishak, Ya'kub and their sons, and what was given to Musa, Isa and the prophets from their Lord, We make no distinction between any of them and to Him we surrender.

There is also a statement of the Prophet Muhammad SAW which shows the spirit of equality. Prophet Muhammad said "there is no superiority of the Arabs over the non-Arabs except because of his piety." The Prophet also said: "Allah does not look at you from your body and your face, but from your heart and your actions."

The meaning of taqwa is explained extensively in the Qur'an. He is not only diligent in carrying out individual worship, but also means good social work, upholding justice, supporting the poor and orphans, respecting others and humanitarian work in a broad sense..

\section{c. Tolerance}

In Arabic, tolerance is commonly referred to as "tasamuh" which means an attitude of letting, being generous, and giving charity. So tolerance (tasamuh) is respecting beliefs or the culture and ethnicity of someone or another group patiently and consciously. The word tolerance comes from the language tolerantie which the verb is tolerant or comes from the English language teleration which the verb tolerates, tolerance also comes from the Latin tolerare which means to hold back, be patient, let others and be open minded to different opinions.

In the large Indonesian dictionary tolerant implies being respectful of positions that are different from one's own. the nature, beliefs and behaviors of others. Tolerance is the belief that religious diversity occurs because of history with all the factors that influence it, both the conditions of space, time, prejudice, desires and interests that differ from one religion to another. Multicultural-based education helps students understand, accept and appreciate people from different ethnicities, cultures, values and religions. Or in other words, students are invited to respect and even uphold plurality and heterogeneity. The multicultural education paradigm implies that individual students learn together with other individuals in an atmosphere of mutual respect, mutual tolerance and mutual understanding. History records that the Messenger of Allah was not only able to reconcile the two tribes of Aus and Khazraj who were always at war, but also able to apply the jargon of "no compulsion in religion" to the people of Medina at that time. This tradition of religious tolerance was continued by Khulafaur Rashidin after the Prophet's death. For example, history records how Ali bin Abi Talib emphasized and appreciated religious freedom when he became the fourth caliph.

\subsection{The reality of a very plural nation}

e-ISSN: $2715-4572$

p-ISSN: 2716-1439 
The richness of religious, ethnic and cultural diversity is like a doubleedged sword. On one hand, this wealth is a treasure that should be preserved and provides nuances and dynamics for the nation, and can also be a starting point for disputes, vertical and horizontal conflicts. The differences in religious groups, ethnic groups, and socio-cultural groups which have increased in terms of size and political significance in recent years, have given rise to demands that social policies and programs be responsive to the needs and interests of such diversity. Meeting this demand will require more cultural sensitivity, rainbow coalitions and pluralistic negotiations-compromise as well. Ethnic tensions and certain interest groups can be accelerated, and as a result there is competition for various limited resources such as jobs, housing, political power, and so on.

All these crucial problems will not be solved without leaving the concept of a pluralistic or plural society and shifting to the concept of a multicultural society.

In many ways ethnicity can be viewed as a self-perception phenomenon: an ethnic community is a community that believes itself to be of the same ethnic origin. The various cultural customs are the same, have a common ancestor, a common history and mythology.

Culture shapes human behavior, attitudes and values. Human behavior is the result of the socialization process, and socialization always occurs in the context of a particular ethnic and cultural environment. Ethnicity can be defined as a collective group consciousness that instills a sense of belonging that comes from membership in a community bound by common ancestry and culture. Humans are social beings who carry natural biological and psychological characters as well as inheritance from the historical background of their ethnic groups, cultural experiences and collective heritage. When an educator claims that his top priority is to treat all students as human beings, regardless of ethnic identity, cultural background, or economic status, he has created a paradox. Humanity of a person cannot be isolated and separated from his culture and ethnicity.

The greatest division between mankind and the main source of conflict comes from culture or civilization. Although the nation-state will be a strong actor, the main conflicts in global politics will occur between different nations and cultural groups. Globalization has given birth to a paradox. The permanent revolt against existing uniformity and integration is culture not state. The part is not the whole. Sects are not religions. Besides ethnicity, religion is also a battlefield. Whatever form of universalism has given gifts in history, such as Jewish, Christian and Islamic monotheism.

In their modern embodiment these three major religions are parochial rather than cosmopolitan. In the process of globalization, the integration of world markets, nation-states, and technologies that enable individuals, corporations and nation-states to reach further corners of the world in a relatively fast

e-ISSN: $2715-4572$

p-ISSN: 2716-1439 
and cheaper time, also leaves those who cannot afford globalization tickets. Therefore, multicultural proponents believe that respect for pluralism will answer tensions between cultures.

\subsection{Islamic Religious Education with Multicultural Insight}

In learning multicultural education in religious institutions, the behavior exemplified by educational leaders has very important values to be instilled early on. Because it is a collection of useful values that can be used as a standard of living. Thus the value of Pancasila is understood in the community of educational institutions in various ways. Leaders are considered the most appropriate means to instill multicultural values, because they contain values, morals and norms that are applied by leaders in playing social functions. 100 Cultural contact will not only lead to tolerance, the recognition of the existence of a separate culture, but can certainly lead to mutual influence, mutual enrichment between cultures.

With the idea of multiculturalism, it will soon be discovered the fact that in fact a person, himself a cultural or religious community, is actually built from various cultures, that in it the lives of others and vice versa. 101 Multicultural education tries to instill in students the importance of religion in quality, not quantity. They are taught how to prioritize substance over religious symbols. The universal messages of religion such as justice, honesty and tolerance are all values that need to be developed in a multicultural society.

Religious education as stated by Sealy (1986), among others has a neo confessional function, which in addition to functioning to increase the diversity of students with their own religious beliefs, also serves to provide the possibility of openness to study and dispute other religions to the extent of tolerated extras, also has a very important place. and strategic for the purpose of planting the attitude of pluralism. In other words, Islamic Education with a multicultural perspective is the Islamic Education learning process in schools that pays attention to all kinds of diversity within the religion of Islam itself.

As is well known, Islam is a religion that is rich in doctrinal interpretations, thus giving birth to various schools of thought, ranging from schools of thought in fiqh to theological thinking. Islamic Education as a system does not only depend on how the inputs and processes are applied, but also how the educational environment is, whether it is sufficient to support the implementation of the process, so as to be able to achieve the expected outputs or results. Regarding the discourse of multiculturalism, reflecting on the educational environment, most schools have not tried to create an environment that supports the creation of students' multicultural insight. Without ignoring theological values such as faith, monotheism, and jihad, these values that can create a multicultural-minded environment need to be emphasized. To support students to get to know and in

e-ISSN: 2715-4572

p-ISSN: 2716-1439 
turn respect each other, and even work together, it is necessary to make efforts to create an environment with a multicultural perspective. Multiculturalbased education helps students understand, accept and appreciate people from different ethnicities, cultures, values and religions. Or in other words, students are invited to respect and even uphold plurality and heterogeneity. The multicultural education paradigm implies that individual students learn together with other individuals in an atmosphere of mutual respect, mutual tolerance and mutual understanding.

\section{Methodology}

In conducting the study, we used a qualitative case study method. The case of this study was a state senior high school in Palu city. Data were gathered through direct field observation, indepth interviews which involve teachers and the school principle. We also analyzed written material ${ }^{11}$, such as the school teaching activities, to understand how the teachers inplement multicultutal based religious education.

We used a qualitative methods in this study wuth several considerations. First, the qualitative methods is helpful when dealing with multiple realities. Second, it can directly present the nature of the relationship between researchers

\footnotetext{
${ }^{11}$.Nurdin, Nurdin, Stockdale, Rosemary, \& Scheepers, Helana. (2014b, 6-9 Jan. 2014). The Role of Social Actors in the Sustainability of EGovernment Implementation and Use: Experience from Indonesian Regencies. Paper presented at the System Sciences (HICSS), 2014 47th Hawaii International Conference on System Science.
}

and informants ${ }^{12}$. Third, this method is more sensitive and adaptable to the many sharpening of the common direction and the patterns of values encountered. ${ }^{13}$ While the data analysis is done using reduction and verification techniques with various data sources. ${ }^{14}$ The reduced data is then analyzed by claiming to the theoretical concepts used in this study.

\section{Result and Discussion}

\subsection{Multicultural Insight Education Learning Planning}

In the presentation of research data, the data is presented in the results of interviews with school principals, the deputy head of the curriculum, and Islamic religious education teachers on August 15, 2018. The presentation of the data here is the disclosure of data obtained from the results of research in the field in accordance with the problems in the thesis, namely

${ }^{12}$.Nurdin, Nurdin, Stockdale, Rosemary, \& Scheepers, Helana. (2014a). Coordination and Cooperation in E-Government: An Indonesian Local E-Government Case The Electronic Journal of Information Systems in developing Countries, 61(3), 1-21.

13Nurdin, Nurdin. (2018). Institutional Arrangements in E-Government Implementation and Use: A Case Study From Indonesian Local Government. International Journal of Electronic Government Research (IJEGR), 14(2), 44-63. doi: 10.4018/ijegr.2018040104

14 Nurdin, Nurdin, \& Aratusa, Zana Chobita. (2020). Benchmarking level interactivity of Indonesia government university websites. TELKOMNIKA Telecommunication, Computing, Electronics and Control, 18(2), 853-859.

e-ISSN: 2715-4572

p-ISSN: 2716-1439 
Implementation Learning Multicultural Education Case Study of Islamic Education Teachers at SMA Negeri 2 Palu.

An educational institution is led by a school principal, in which the principal is authorized to lead, supervise and develop, evaluate, and facilitate various activities both related to schools, teachers, employees/staff or to their students. So the role of the principal is very important for the ongoing learning process in a school.

SMA Negeri 2 Palu is a school with multicultural students from various regions, but in terms of learning, methods, even the activities are also multi-faceted. Therefore, this school is one of the favorite schools of the Palu city community with a national standard status, even last year held a student exchange to the United States so that it has its own attraction to develop student education.

In this case, the researcher conducted interviews with the principal relating to the role of the school and the role of the principal in learning, the results of which were as follows::

"First to facilitate clear learning, secondly to implement a hidden curriculum such as Praying, Attitude, Knowledge, Skill and Action or abbreviated as P.A.K.S.A " because here there are five religions, we are in accordance with the things outlined by the government, we must provide existing religious teachers, If for example in the school there are people of other religions, of course, the school will try to provide teachers, so that in religious studies they do not experience any obstacles.". 15

From the results of the interviews, it was found that the curriculum applied in SMA Negeri 2 Palu was basically the same as the curriculum applied in other public schools. P.A.K.S.A (Pray, Attitude, Knowledge, Skill and Action) is not a curriculum, but is a motto or learning model that applies at SMA Negeri 2 Palu. This is reinforced by the statement of :

"P.A.K.S.A is the learning model that we apply, the assessment model. We evaluate students based on P.A.K.S.A (Pray, Attitude, Knowledge, Skill and Action) the curriculum is still curriculum 13 but the assessment that we apply is P.A.K.S.A". ${ }^{16}$

Basically, the use of the curriculum at SMA Negeri 2 Palu is a character-based curriculum 13 whose assessment system refers to the P.A.K.S.A (Pray, Attitude, Knowledge, Skill and Action).

\section{B. Implementation of Multicultural Insight Education Learning}

Education cannot be separated from the learning process in a particular educational institution. The

${ }^{15}$ Eddy Siswanto, Wawancara di ruang Kepsek SMA Negeri 2 Palu. Rabu, 15 Agustus 2018 Pukul 10.15 WITA

16 Gamar, Waka Kurikulum, wawancara diruang Waka Kurikulum SMA Negeri 2 Palu, Rabu, 15 Agustus 2018, pukul 10.50 WITA

e-ISSN: 2715-4572

p-ISSN: 2716-1439 
implementation of learning must be planned and conceptualized so that its implementation is expected to run smoothly and as expected. Many things that support the ongoing process of implementing learning include classrooms, media, learning resources, method strategies, the cognitive abilities of teachers to interact with students, the curriculum applied and so on.

Learning activities and active learning days at SMA Negeri 2 Palu are the same as other public schools. From the results of interviews with Islamic Education teachers and the deputy head of the curriculum related to the implementation of learning, the following data were obtained:

"My study hours are today, tomorrow and Thursday, the hours are from 12.00 to 15.00 , usually there is not enough time because some are still resting. The lessons are Monday-Friday, so it is full day, Saturday-Sunday specialization for students according to their respective skills." 17

Islamic religious education learning at SMA Negeri 2 Palu is held on Monday for class X, Wednesday for class XI, and Thursday for class XII while the time is from 12.00 to 15.00 based on indonesian middle time. The implementation of learning is sometimes not on time because some students are still eating in the canteen, some are

\footnotetext{
${ }^{17}$ Gamar, Waka Kurikulum, wawancara diruang Waka Kurikulum SMA Negeri 2 Palu, Rabu, 16 Agustus 2018, pukul 10.50 WITA
}

praying, and sometimes there are students sleeping in the mosque.

Learning Islamic religious education at SMA Negeri 2 Palu is usually in the form of a discussion forum that discusses daily problems related to religion, a cult is held after each midday prayer which is rotated alternately between one student and another. The provision of fiqh material given directly by Islamic religious teachers. This is done to make it easier to monitor all activities during school hours.

The learning process in Islamic religious education always pays attention to individual educator participants and respects the dignity and freedom of thought, expresses opinions and establishes their position, so that for students, learning is fun and at the same time encourages their personality to develop optimally, while for teachers, the learning process is an obligation. which is worth worship, which must be accounted for.

The implementation of learning Islamic religious education with a multicultural perspective at SMA Negeri 2 Palu prioritizes a sociological approach, which is an approach that emphasizes the relationship between humans and other humans. The students' backgrounds are different in terms of life, ethnicity, tradition, thus making students' mindsets different from each other even though they are both Muslim.

Learning strategies have an important role to support the learning process. The application of the strategy usually goes hand in hand with the e-ISSN: $2715-4572$ p-ISSN: 2716-1439 
application of the method in learning. In this case, the results of interviews with Islamic Education teachers are as follows

"learning strategies include active learning, quantum learning, but I often use quantum learning, which is often active learning." 18

In learning Islamic religious education instill character values and multicultural values. One of them is togetherness and respect for differences, SMA Negeri 2 Palu is a school that has different backgrounds and cultures from various regions. So there needs to be a value that unites them. In the implementation of learning, the priority is the values of togetherness such as tolerance, living together, mutual respect and mutual help.

With the awareness of the many differences between students, there will be no division with other students, both with different aqidah who are fellow Muslims, even fellow students with different religions, ethnicities and so on. They realize that in the differences there are similarities, namely both children of the Indonesian nation. Both in the same school environment, come from various regions with poor family backgrounds, orphans and of course there are still many similarities between the students of SMA Negeri 2 Palu. So that in terms of the implementation of multiculturalminded religious education learning at

\footnotetext{
${ }^{18}$ Hapsah Jamalia, Guru PAI kelas XI, wawancara di ruang Guru SMA Negeri 2 Palu. Kamis 16 Agustus 2018, pukul 09:30 WITA
}

SMA Negeri 2 Palu runs smoothly and well.

Basically all kinds of differences in terms of differences in religion, ethnicity, race, and class even the belief in the understanding that students profess does not make a problem, because they believe more that they are all in SMA Negeri 2 Palu is because it starts from these differences so that they can all be elected as students of SMA Negeri 2 Palu. With all the differences that exist, they unite to realize the goals of the ideals of the Indonesian nation. This is reinforced from several interviews as follows:

"the most important part of this school is multiculturalism, the differences still exist but those differences are the glue that binds everything here so that it can be a way to facilitate how we tolerate."19

With the existence and diversity of races, religions, and ethnic groups, even understanding is considered as a means to expand knowledge and strengthen brotherhood ties between fellow students, both of the same religion and with students of different religions. Based on the diversity of religions, ethnicities, races, students become more compact and together. This is shown by various activities and performances which are often the main attraction for the community.

From the results of the interview, it was obtained information that both

${ }^{19}$ Eddy Siswanto, Wawancara di ruang

Kepsek SMA Negeri 2 Palu. Senin, 20 Agustus 2018 Pukul 10.50 WITA 
the principal, vice head of the curriculum, Islamic Education teachers at SMA Negeri 2 Palu always respond positively by supporting the implementation of religious activities that involved all students to participate in these activities.

\section{Conclusion}

Learning planning for multicultural education is a case study of Islamic Education teachers at SMA Negeri 2 Palu. Learning planning emphasizes the integration of multicultural values: fairness. Responsibility, religious, awareness, rights and obligations, equality, tolerance, respect for diversity, honesty, discipline contained in the Learning Program Plan and in the syllabus.

The implementation of multicultural education learning as a case study of Islamic Education teachers at SMA Negeri 2 Palu with Islamic religious education is provided through a sociological approach that contains multicultural values such as fairness, responsibility, religion, awareness of rights and obligations, equality, tolerance, respect for diversity, honest, disciplined and so on. However, the most well-executed and most dominating value is the value of togetherness and mutual respect.

Evaluation of multicultural education learning in the case study of Islamic Education teachers at SMA Negeri 2 Palu by applying an evaluation model by paying attention to integrated multicultural values in the cognitive, psychomotor, affective and P.A.K.S.A
(Pray, Attitude, Knowledge, Skill and Action) domains.

\section{REFERENCES}

Aly Abdullah, Pendidikan Islam Multikultural di Pesantren, yogyakarta: Pustaka

Belajar, 2011.

Arikunto Suharismi, Prosedur Penelitian

Suatu Pendekatan Praktek, Jakarta:

Rineka Cipta, 2006

Azra Azyumardi, Nilai-nilai Pluralisme

Dalam Islam; Bingkai Gagasan yang

Berserak, Bandung: Cet, Ke-1 Nuansa, 2005.

Aswan Zain dan Syaiful Bahri Djamarah, Strategi Belajar Mengajar, Jakarta:

Rineka Cipta, 2006.

A. Bank James. Handbook of Research on Multikultural Education (http:/ / www.

educationworld. com, diakses tanggal 25 April 2018.

Asih Menanti dan Usman Pelly, TeoriTeori Sosial Budaya, Jakarta: Dirjen Dikti

Depdikbud,1994.

Baidhawy Zakiyudin, Pendidikan Agama Berwawasan multikultural,

Jakarta: Erlangga, 2005.

Dian Andayani dan Abdul Majid, Pendidikan Agama Islam Berbasis Kompetensi;

Konsep dan Implementasi Kurikulum 2004, Bandung: Remaja

Rosdakarya, 2005

Daradjat Zakiah, et.al, Ilmu Pendidikan Islam, Jakarta: Cet. Ke-7 Bumi Aksara, 2008.

Gamar, Waka Kurikulum SMA Negeri 2 Palu, Wawancara di Ruang Waka

Kurikulum 
Hilmy Masdar, Menggagas Paradigma Pendidikan Berbasis Multikulturalisme, Jurnal Ulumuna, Volume VII Edisi 12 Nomor 2 Juli-Desember 2003.

Harto Kasinyo, Model Pengembangan Pendidikan Agama Islam Berbasis

Multikultural, Jakarta: Rajawali

Press, 2012.

Hamalik Oemar, Perencanaan Pengajaran Berdasarkan Pendekatan Sistem,

Jakarta: Bumi Aksara, 2008

J. Moleong Lexy, Metode Penelitian Kualitatif, (Bandung: PT. remaja Rosda

Karya, 2001

Jurnalis Etek, Tayar Yusuf, Keragaman Teknik Evaluasi Dan Metode

Penerapan Jiwa Agama, Jakarta: Cet

Ke- 1 Ind-Hill -Co, 1987

Jamalia Hapsah, Guru PAI SMA Negeri 2 Palu, Wawancara di Ruang Guru dan Mesjid

J. Sarwono, Metode Penelitian Kuantitatif dan Kualitatif, Yogyakarta: Graha Ilmu, 2006

Kamus Besar Bahasa Indonesia, Departemen Pendidikan dan Kebudayaan,

Jakarta: Balai Pustaka, 1990.

Kusrini Siti dkk, Keterampilan Dasar Mengajar (PPL 1), Berorientasi pada

Kurikulum Berbasis Kompetensi, Malang universitas UIN Malang , 2008

Komariah dan D. Satori, Metodologi Penelitian Kualitatif (Bandunga : Alfabeta, 2010

Lilik Nur Kholidah \& Ahmad Munjin

Nasid, Motode dan Teknik Pembelajaran Pendidikan Agama Islam, Bandung:

Refika Aditama, 2009

Luluk Yunan Ruuhendi dan Ali Maksum, Paradigma Pendidikan Universal, Yogyakarta: IRCiSod, 2004.
M. Dahlan Al Barry dan Pius A. Partanto, Kamus Ilmiah Populer, PT. Arkola Surabaya, 2005.

Mahfud Choirul, Pendidikan Multikultural, Yogyakarta: Cet, Ke-1 Nuansa

Pustaka Pelajar, 2014.

Maksum Ali, Pluralisme dan Multikulturalisme Paradigma Baru;Pendidikan

Agama Islam di Indonesia, Yogyakarta: Aditya Media, 2011.

Muliadi Erlan, Urgensi Pembelajaran Pendidikan Agama Islam Berbasis

Multikultural Di SMAN 2 Sleman.

Tesis 2012

Munjin Ahmad, metode dan teknik pembelajaran pendidikan agama islam,

Bandung: PT. Refika Aditama, 2009.

Mulyasana Dedy, Pendidikan Bermutu dan Saing, Bandung: PT.Remaja

Rosdakarya, 2011

Mulyasa E, Implementasi Kurikulum 2004

Panduan Belajar KBK, Bandumg:

PT.Remaja Rosdakarya, 2004

Muhaimin dkk, Strategi Belajar Mengajar dan Penerapannya dalam

Pembelajaran PAI, Surabaya: CV.

Citra Media, 1996

Muhaimin, Nuansa Baru Pendidikan Islam

: Mengurai Benang Kusut Dunia

Pendidikan, Surabaya: CV. Citra Media, 1996.

Maslikhah, Quo Vadis Pendidikan Multikultur, Salatiga: STAIN Salatiga Press,

2007

Naim Ngainun, Pendidikan Multikultural; Konsep dan Aplikasi,

yogyakarta: Ar-ruzz Media, 2008

e-ISSN: $2715-4572$

p-ISSN: 2716-1439 
Nurdin, Nurdin, Stockdale, Rosemary, \& Scheepers, Helana. (2014a). Coordination and Cooperation in E-Government: An Indonesian Local E-Government Case The Electronic Journal of Information Systems in developing Countries, 61(3), 1-21.

Nurdin, Nurdin. (2018). Institutional Arrangements in E-Government Implementation and Use: A Case Study From Indonesian Local Government. International Journal of Electronic Government Research (IJEGR), 14(2), 44-63. doi: 10.4018/ijegr.2018040104

Nurdin, Nurdin, Stockdale, Rosemary, \& Scheepers, Helana. (2014b, 6-9 Jan. 2014). The Role of Social Actors in the Sustainability of E-Government Implementation and Use: Experience from Indonesian Regencies. Paper presented at the System Sciences (HICSS), 2014 47th Hawaii International Conference on System Science.

Nurdin, Nurdin, \& Aratusa, Zana Chobita. (2020). Benchmarking level interactivity of Indonesia government university websites. TELKOMNIKA Telecommunication, Computing, Electronics and Control, 18(2), 853-859.

Rosyada Dede, Paradigma Pendidikan Demokratis:Sebuah Model Pelibatan Masyarakat Dalam Penyelenggaraan Pendidikan, Jakarta: Kencana, 2004

Rofi'in Zaenuri, Implementasi Pendidikan Agama Islam dalam Membentuk Karakter Toleran Perspektif Multikulturalisme (Studi Kasus di SMP.
Rusli, Rusli, \& Nurdin, Nurdin. (2021). Understanding Indonesia millennia Ulama online knowledge acquisition and use in daily fatwa making habits. Education and Information Technologies. doi: 10.1007/s10639021-10779-7

Rusli, Rusli. (2013). The Role of Musalahah in Conflict Resolution: A Historical Perspective. HUNAFA: Jurnal Studia Islamika, 10(2), 203-220.

Rusli, Rusli. (2018). Fikih Ekologi dan Kearifan Tradisional: Tinjauan Terhadap Konsep Ihya' al-Mawat dan Hima. HUNAFA: Jurnal Studia Islamika, 5(3), 287-298.

Negeri 1 dan 2 Kaloran Kabupaten Temanggung) Tesis 2017

Siswanto Eddy, Kepala Sekolah SMA Negeri 2 Palu, Wawancara di Ruang Kepsek

Samsidar, Guru PAI SMA Negeri 2 Palu, Wawancara di Ruang Guru dan Mesjid

Sagala Syaiful, Konsep dan Makna Pembelajaran, Bandung: Alfabeta, 2003.

Sukmadinata Nana Syaodih Pengembangan Kurikulum Teori Dan Praktek,

Bandung: PT. Remaja Rosdakarya, 2008.

Sofyan Ahmad, M.Pd, dkk, Evaluasi Pembelajaran IPA Berbasis Kompetensi,

Jakarta: UIN Cet ke-1 Jakarta Press, 2006 Suryana Yaya, Pendidikan Multikultural; Suatu Upaya Pengamatan Jati Diri Bangsa KonsepPrinsip Praktek, Bandung: Pustaka Setia, 2015. 
Sunarto Kamanto, Multicultural Education in Schools, Challenges in its Implementation, dalam Jurnal Multicultural Education in Indonesia and

South East Asia, edisi I, tahun 2004.

Sada Clarry, Multicultural Education in Kalimantan Barat; an Overview, dalam

JurnalMulticultural Education in Indonesia and South East Asia, edisi I,tahun 2004

Syarifuddin M dan Mey. S. “ Pendidikan Berwawasan Multikultural di Madrasah",MPA No.247 th XX April 2007

Saebani dan Afifudin, Metodologi Penelitian Kualitatif (Bandung: Pustaka Setia, 2009

Truna S. Doddy, Pendidikan Agama Islam Berwawasan Multikulturalisme, Seri Disertasi, Kementrian Agama RI, 2010.

Tilaar H.A.R, Pendidikan Multikultural dalam H.A.R Tilaar, Kekuasaan dan Pendidikan: Suatu Tinjauan dari Perspektif Studi Kultur, Magelang: Indonesia tera, 2003.

UU RI. Nomer 20 tahun 2003 tentang Sistem Pendidikan Nasional

Uhbiyati Nur, Ilmu Pendidikan Islam 1, (Bandung: Cet. Ke-3 CV. Pustaka Setia,

2005).

Zamroni, Pendidikan Untuk Demogras, Tantangan Menuju Civil Society, Yogyakarta Bigraf Publishing, 2001.

Yakin Ainul M, Pendidikan Multikultural: Cross-Cultural Understanding Untuk Demokrasi dan Keadilan, Yogyakarta: Pilar Media, 2005. 